\title{
RE-ORIENTASI PEMANFAATAN DANA DESA DALAM RANGKA MENDUKUNG RENCANA KERJA PEMERINTAHTAHUN 2020
} (Upaya Peningkatan Sumber Daya Manusia untuk Pertumbuhan Berkualitas di Kabupaten Bejonegoro)

\author{
FIRREAN SUPRAPTO \\ UNIVERSITAS DARMA PERSADA JAKARTA
}

aansuprapto@gmail.com

\begin{abstract}
Abstrak
Mencermati kewenangan yang diberikan dan dimiliki desa untuk mengurus dan mengatur warga masyarakatnya sendiri secara mandiri maka menjadi keharusan bahwa desa melalui pemrintah desa memerlukan anggaran dalam pelaksanaan kewenangan di desa, tulisan ini bertujuan untuk mencoba melihat dan membahas mengenai beberapa langkah dan upaya yang dapat dilakukan oleh pemerintah Bojonegoro untuk memaksimalkan dana desa dibeberapa desa yang disebutkan dalam jurnal ini dan menjadi contoh kasus di kabupaten Bojonegoro. Metode Penelitian yang digunakan ialah berjenis kualitatif dengan menggunakan sumber data melalui kajian pustaka dan studi dokumentasi. Dari penelitian yang dilakukan ini di ketahui bahwa Alokasi dana desa (ADD) yang bersumber dari dana perimbangan keuangan pemerintah pusat dan daerah keberadaanya belum dapat dikelola dengan maksimal, sehingga belum menjadi instrument utama yang hadir dalam mewujudkan kesejahteraan masyarakat di beberapa desa di kabupaten Bojonegoro. Pada sisi lainnya terkait keberadaan ADD maka pemerintahan Bojonegoro perlu meningkatkan pengetahuan SDM pemerintahan desa dalam mengelola dan menggunakan keuangan ADD sebagaimana yang diharapkan dari peraturan perundang-undangan yang berlaku dengan mengikutkannya dalam kegiatan pelatikan atau workshop.
\end{abstract}

Kata kunci: re-orientasi, dana desa, sumber daya manusia, bojonegoro.

\section{A. PENDAHULUAN}

Perbincangan mengenai desa akhir-akhir ini kian mengemuka dan aktual. Bagaimana tidak, keberadaan desa pada masa ini memiliki kewenangan yang cukup besar disbanding masa sebelumnya, baik dalam pengelolaan anggaran maupun dalam pengembangan kawasan yang dimiliki, dengan disahkannya undang-undang desa menjadikan keberadaan desa saat ini betul-betul menjadi daya tarik dan perebutan bagi sebagian orang.Desa seolah menjadi objek baru bagi 
elit-elit lokal yang memiliki segalanya untuk tidak hanya diperebutkan sebagai panggung strategis dalam upaya mengumpulkan sumber daya ekonomi, tapi juga menjadi wadah untuk memproduksi kekuasaan-kekuasaan kecil di desa yang terkadang sangat memonopoli laju perkembangan di desa tersebut. Satu sisi memiliki dampak positip untuk menjadikan desa berkembang dan bersaing namun disisi lain menjadikan itu sebagai penghambat utama dalam pembanganunan di desa.

Berkelindan dengan hal di atas, sebagai sebuah konsepsi ideal terkait pandangan dan pemahaman tentang desa, maka menurut H.A.W. Widjaja dalam bukunya yang berjudul "Otonomi Desa" menyatakan bahwa Desa adalah sebagai kesatuan masyarakat hukum yang mempunyai susunan asli berdasarkan hak asalusul yang bersifat istimewa. Landasan pemikiran dalam mengenai Pemerintahan Desa adalah keanekaragaman, partisipasi, otonomi asli, demokratisasi dan pemberdayaan masyarakat. ${ }^{1}$

Dalam hal ini, desa menjadi sangat otonom seperti yang dikemukakan oleh Widjaja, yang menyatakan bahwa otonomi desa merupakan otonomi asli, bulat, dan utuh bukan merupakan pemberian dari pemerintah. ${ }^{2}$ Sebaliknya pemerintah berkewajiban menghormati otonomi asli yang dimiliki oleh desa tersebut. Senada dengan itu Taliziduhu Ndrahamenjelaskan sebagai berikut : a) Otonomi desa diklasifikasikan, diakui, dipenuhi, dipercaya dan dilindungi oleh pemerintah, sehingga ketergantungan masyarakat desa kepada "kemurahan hati" pemerintah dapat semakin berkurang. b) Posisi dan peran pemerintahan desa dipulihkan, dikembalikan seperti sediakala atau dikembangkan sehingga mampu mengantisipasi masa depan dan potensi yang dimiliki desa. ${ }^{3}$

Lebih jauh, melalui kewenangan yang dimiliki desa untuk mengurus dan mengatur warga masyarakatnya, maka dapat dikatakan bahwa desa telah diberi kekuasaan untuk mengurus dirinya sendiri atau dalam kata lain, telah diberikan otonomi terhadap desa dengan tujuan agar tercipta kesejahteraan bagi warganya. Sebagai konsekuensi logis adanya kewenangan dan tuntutan dari pelaksanaan otonomi desa adalah tersedianya dana yang cukup. Sadu Wasistiono menyatakan bahwa pembiayaan atau keuangan merupakan faktor essensial dalam mendukung penyelenggaraan otonomi desa, sebagaimana juga pada penyelenggaraan otonomi daerah. ${ }^{4} \mathrm{Hal}$ ini sejalan dengan asumsi publik yang terbentuk yang mengatakan

\footnotetext{
${ }^{1}$ Widjaja, HAW,Otonomi Desa, (Jakarta: PT Raja Grafindo Persada, 2003), 3.

${ }^{2}$ Widjaja, HAW,Otonomi Desa, 165.

${ }^{3}$ TaliziduhuNdraha,Metodologi Ilmu Pemerintahan, (Jakarta : Rineka Cipta, 1997), 12.

${ }^{4}$ SaduWasistiono, Prospek Pengembangan Desa, (Bandung: Fokusmedia, 2006), 107.
} 
bahwa otonomi seringkali indentik dengan istilah outo money, maka untuk mengatur dan mengurus rumah tangganya sendiri desa membutuhkan dana atau biaya yang memadai sebagai dukungan pelaksanaan kewenangan yang dimilikinya.

Mengacu kepada Peraturan Pemerintah Nomor 72 Tahun 2005 tentang Desa dimana Penyelenggaraan Urusan Pemerintah Desa yang menjadi Kewenangan Desa didanai dari Anggaran Pendapatan dan Belanja Desa dan Bantuan Pemerintah Desa sesuai dengan surat Menteri Dalam Negeri Nomor: 140/640SJ tanggal 22 Maret 2005 tentang Pedoman Alokasi Dana Desa dari pemerintah Kabupaten kepada Pemerintah Desa, serta Peraturan Menteri Dalam Negeri Nomor 37 tahun 2007 tentang Pedoman Pengelolaan Keuangan Desa. Desa mempunyai hak untuk memperoleh bagi Hasil Pajak Daerah dan Retribusi Daerah Kabupaten serta bagian dari Dana Perimbangan Keuangan Pusat dan Daerah yang diterima oleh Kabupaten sesuai Peraturan Pemerintah Nomor 72 Tahun 2005 Pasal 68. Perolehan bagian Keuangan Desa dari Kabupaten penyalurannya melalui Kas Desa sesuai dengan pasal 2A Undang-Undang Nomor 34 Tahun 2000 tentang perubahan atas Undang-Undang Nomor 18 Tahun 1997 tentang Pajak dan Retribusi Daerah. Melalui ketentuan dari peraturan ini jelas mengamanatkan kepada Pemerintah Kabupaten untuk mengalokasikan dana perimbangan yang diterima Kabupaten kepada Desa-desa dengan memperhatikan prinsip keadilan dan menjamin adanya pemerataan.

Pemberian Alokasi Dana Desa merupakan wujud dari pemenuhan hak desa untuk menyelenggarakan otonominya agar tumbuh dan berkembang mengikuti pertumbuhan dari desa itu sendiri berdasarkan keanekaragaman, partisipasi, otonomi asli, demokratisasi, pemberdayaan masyarakat dan meningkatkan peran Pemerintah Desa dalam memberikan pelayanan dan meningkatkan kesejahteraan masyarakat serta menghela percepatan pembangunan dan pertumbuhan wilayahwilayah strategis. Sehingga, hal ini dapat mengembangkan wilayah-wilayah tertinggal dalam suatu sistem wilayah pengembangan. Keuangan desa adalah hak dan kewajiban dalam rangka penyelenggaraan pemerintahan desa yang dapat dinilai dengan uang termasuk didalamnya segala bentuk kekayaan yang berhubungan dengan hak dan kewajiban desa. Dengan kondisi stabilitas keuangan yang dimiliki oleh desa setidaknya juga menjadi peluang dan pendorong penting untuk berkompetisi menjadi lebih maju dibanding desa-desa lain yang ada disekitarnya masing-masing, hal ini dapat dilakukan dengan cara bersinergi desa yang satu dengan desa yang lain. Sebagaimana hal ini juga sesuai dengan apa yang dikemukakan oleh Bempah, menurutnya kemajuan perekonomian pedesaan yang 
satu dengan perekonomian pedesaan yang lain sangat berhubungan, sehingga diperlukan upaya nyata dalam rangka memajukan perekonomian pedesaan. Upaya nyata perlu dengan cepat dan tepat dilakukan sehingga menciptakan akselerasi kemajuan perekonomian di daerah tersebut. ${ }^{5}$

Apalagi saat ini untuk melihat segala bentuk pencapaian yang sudah dilakukan oleh desa dapat dengan mudah bisa dinilai oleh publik, dengan indikator yang cukup sederhana, melalui pemanfaatan dana desa yang dimiliki apakah desa tersebut kategori desa maju, berkembang atau terbelakang, dan sebagaimana yang diketahui bersama bahwa bulan-bulan inilah merupakan momentum dimana semua Kabupaten/Kota sedang sibuk-sibuknya mempersiapkan laporan akhir tahun terhadap semua kegitan desa yang sudah dilakukan, yang disepakati dulu saat Musrembang desa agenda kebijakannya yang sering kita sebut dengan istilah "Musyawarah Perencanaa Pembangunan (MUSRENBANG)", tingkat desa, naik ke kecamatan dan MUSRENBANG ditingkat kabupaten, yang merupakan agenda siklus tahunan yang dilakukan pemerintah baik pemerintah daerah, maupun pemerintah provinsi dalam rangka penyusunan perencanaan pembangunan. Termasuk juga dalam hal ini Kabupaten Bojonegoro merupakan salah satu kabupaten di Jawa Timur yang laju pertumbuhan ekonominya di dorong oleh sektor Migas.Pertumbuhan ekonomi di Bojonegoro pada 2015 tumbuh sebesar $17,42 \%$ (+Migas) dan merupakan peningkatan yang luar biasa jika dibandingkan dengan tahun sebelumnya yang hanya sebesar $2,36 \%{ }^{6}$

${ }^{5}$ RidwanBempah, Analisis Alokasi Dana Desa dalam Meningkatkan Pendapatan Penduduk Miskin di Kecamatan Poso Pesisir Kabupaten Poso. E-Jurnal Katalogis, Vol. 1 No. 2, April 2013, 15.

${ }^{6}$ Sumber: http://www.bojonegorokab.go.id.,diolah 2019, diakses tanggal 15-08-2019. 
Gambar 1. Laju Pertumbuhan Ekonomi dan Tingkat Inflasi Kabupaten Bojonegoro Tahun $2015-2017$

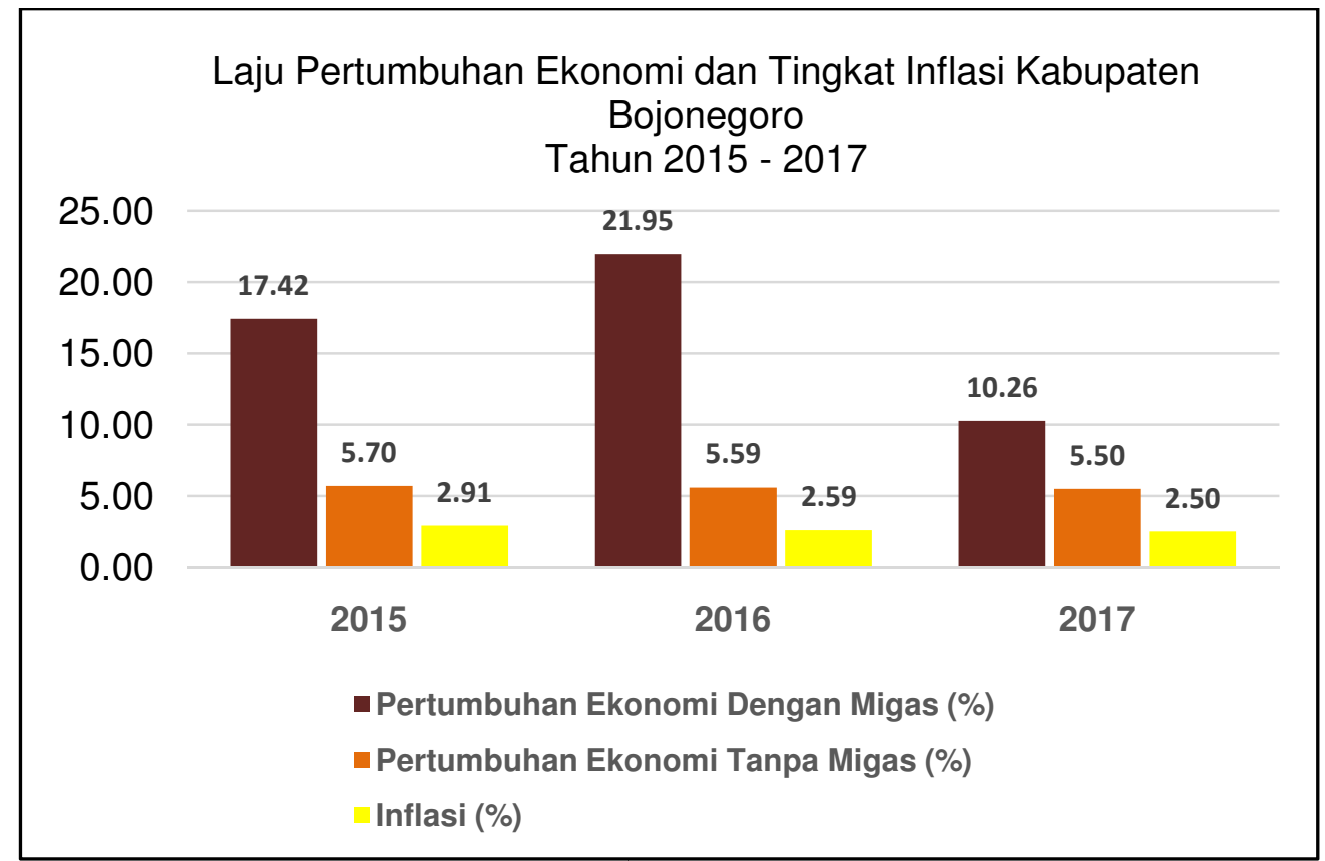

Sumber: http://www.bojonegorokab.go.id.,diolah 2019.

Dengan potensi yang dimiliki Bojonegoro tentu dibutuhkan sebuah perencanaan yang berbasis THIS (Tematik, Holistik, Integratif dan Spasial) menjadi penting untuk dapat diterapkan di kabupaten ini.MUSRENBANG DES adalah salah satu bagian instrumen penting dalam permumusan sebuah kebijakan khususnya kebijakan yang benar-benar diinisiasi dari masyarakat.Ketentuan ini tentu saja sudah termuat dalam UU No. 25 Tahun 2004 tentang Sistem Perencanaan Pembangunan Nasional. Lebih lanjut, Kabupaten Bojonegoro tentu akan melihat pula prioritas nasional yang termuat dalam RKP 2020 yaitu: (PN1) Pembangunan Manusia dan Pengentasan Kemiskinan, (PN 2) Konektivitas dan Pemerataan, (PN3) Nilai Tambah Ekonomi dan Kesempatan Kerja, (PN 4) Ketahanan Pangan, Air, Energi, dan Lingkungan Hidup, (PN 5) Stabilitas Pertahanan dan Keamanan.

Spirit itu tergambar jelas dari kondisi ideal pembangunan masyarakat desa yang diungkapkan oleh Surjadi, Pembangunan Masyarakat Desa adalah sebagai suatu proses dimana anggota-anggota masyarakat desa pada awalnya 
mendiskusikan dan menentukan keinginan mereka, kemudian merencanakan dan mengerjakan bersama untuk memenuhi keinginan mereka tersebut. ${ }^{7}$

Saat ini, proses MUSRENBANG memang telah berjalan sebagaimana mestinya.Akan tetapi, ada hal menarik yang menjadi pengamatan penulis khususnya pemanfaatan Kebijakan Dana Desa.Kebijakan Dana Desa yang selama ini berjalan tampak kurang optimal dan terukur khususnya di beberapa tempat sebagaimana penulis singgahi.Misalkan, di Desa Ngampel, dan Sambiroto Kecamatan Kapas dimana kedua desa tersebut merupakan desa yang wilayahnya merupakan lokasi eksplorasi pertambangan MIGAS. Disana masih banyak ditemukan para petani yang mengeluh akan lahan pertaniannya serta mengeluh akan penghasilan yang mereka dapatkan. Terlebih, mereka harus berhutang untuk mempertahankan kehidupan bertani mereka agar dapat menyambung hidup mereka.

\section{B. METODE PENELITIAN}

Jenis penelitian yang digunakan dalam penelitian ini adalah penelitian kualitatif dengan metode pendekatan deskiptif.Sumber data dalam penelitian ini diambil dengan menggunakan metode studi pustaka dan metode dokumentasi dengan mengambil sampel contoh kasus dibeberapa desa di Kabupaten Bojonegoro Jawa Timur, lalu diselaraskan dengan data Pemkab Bojonegoro untuk ditelaah lebih jauh.

\section{ANALISIS ANTAR KEBIJAKAN DESA DAN DANA DESA}

Kebijakan Dana Desa saat ini menjadi produk kebijakanpaling menarik untuk ditelaah lebih jauh.Banyak para kalangan akademisi, pemerhati kebijakan dan masyarakat pada umumnya selalu memperbincangkan masalah implementasidari kebijakan Dana Desa yang hadir sebagai bentuk amanah dari UU No. 6 Tahun 2014 tentang Desa. Lebih lanjut, perbincangan akan Dana Desa dapat dirujuk di dalam UU No. 6 Tahun 2014 pada Bab VIII Keuangan Desa dan Aset Desa pasal 71 menyebutkan Keuangan Desa adalah semua hak dan kewajiban desa yang dapat dinilai dengan uang serta segala sesuatu berupa uang dan barang yang berhubungan dengan pelaksanaan hak dan kewajiban desa. Pendapatan Desa sebagaimana dimaksud pada pasal 71 kemudian dijelaskan di pasal 71 dimana pendapatan desa bersumber dari: (a) pendapatan asli desa terdiri dari hasil usaha,

\footnotetext{
${ }^{7}$ Surjadi, Pembangunan Masyarakat Desa, (Bandung: Mandar Maju, 1995), 1.
} 
hasil aset, swadaya, dan partisipasi, gotong royong dll, (b) alokasi anggaran pendapatan dan belanja negara, (c) bagian dari hasil pajak daerah dan retsibusi daerah Kabupaten/Kota, (d) alokasi dana desa yang merupakan bagian dari perimbangan yang diterima kabupaten/kota, (e) bantuan keuangan dari anggaran pendapatan dan belanja daerah provinsi dan anggaran pendapatan dan belanja daerah kabupaten/kota, (f) hibah dan sumbangan yang tidak mengikat dari pihak ketiga, dan (g) lain-lain pendapatan desa yang sah.

\section{Gambar 2. Diagram Alur Antar Kebijakan Desa dan Dana Desa}

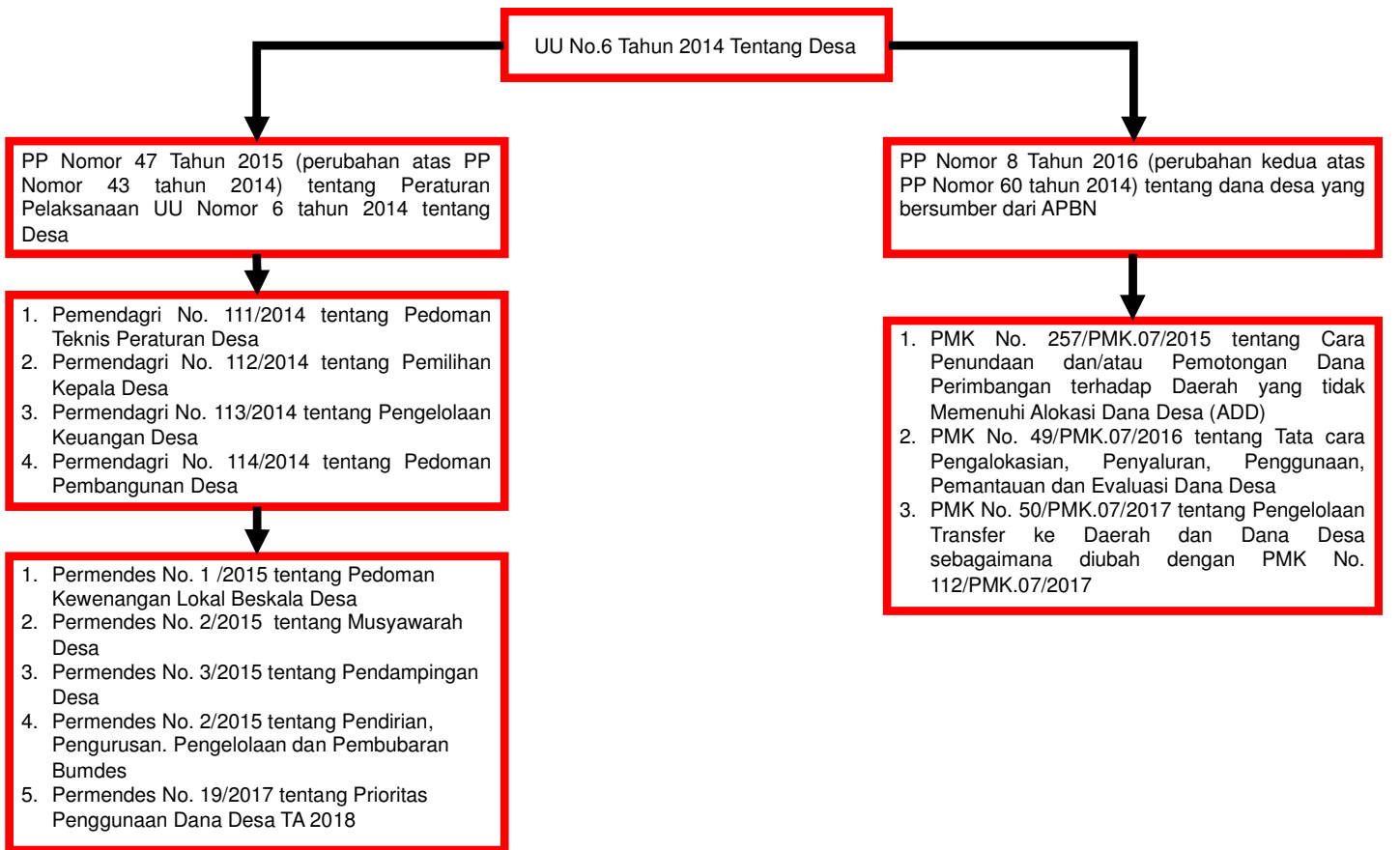

Sumber: Analisis Antar Regulasi, oleh Penulis 2019.

Alokasi dana desa sebagaimana dimaksud pada (huruf d paling sedikit 10\%) dari dana perimbangan yang diterima Kabupaten/Kota dalam anggaran Pendapatan dan Belanja Daerah setalah dikurangi Dana Alokasi Khusus. Anggaran pendapatan dan belanja desa terdiri atas bagian pendapatan, belanja dan pembiayan desa. Kemudian, rancangan anggaran pendapatan dan belanja desa diajukan oleh KepalaDesa dan dimusyawarahkan bersama Badan Permusyawaratan Desa. Hasil musyawarah tersebut akan ditetapkan sebagai 
anggaran Pendapatan dan Belanja Desa setiap tahun dengan Peraturan Desa (pasal 73).

Pengertian Dana Desa sendiri sejauh ini dimaknai sebagai dana yang berasal dari APBN yang peruntukkannya digunakan dalam pelaksanaan pembangunan dan pemberdayaan masyarakat. Dilihat dari segi tujuan, kehadiran Dana Desa bertujuan untuk: (1) Meningkatkan pelayanan publik di desa, (2) Mengentaskan kemiskinan, (3) Memajukan perekonomian desa, (4) Pengatasi kesenjangan pembangunan antar desa, dan (5) Memperkuat masyarakat desa sebagai subjek pembangunan. Untuk itu, harapan dengan adanya Dana Desa dapat digunakan untuk: (1) Penyelenggaran pemerintahan: Digunakan untuk mendukung terselenggaranya fungsi pemerintahan desa, (2) Pembangunan Desa: Pembangunan pendidikan, kesehatan, pekerjaan umum dan lain-lain, (3) Pembinaan Kemasyarakatan: Meningkatkan peran serta kesadaran masyarakat/lembaga kemasyarakatan desa yang mendukung proses pembangunan desa, (4) Pemberdayaan Masyarakat Desa: Meningkatkan pemahaman kapasitas masyarakat dalam meningkatkan kesejahteraan masyarakat, dan (5) Penanggulangan Bencana, Keadaan Darurat dan Mendesak Desa (Perubahan Permendagri N0.20 Tahun 2018 tentang pengelolaan Dana Desa).

\section{Permasalahan dan Penyalahgunaan Kebijakan Dana Desa}

Saat ini, penyerapan program dana desa yang dipantau mulai Tahun 2015 mencapai 82,72\%, kemudian penyerapan naik menjadi 97,65\% pada Tahun 2016 dan kembali naik menjadi 98,54\% pada Tahun 2017. Pada Tahun 2018 penyerapan dana desa mencapai $99 \%$ dari yang dialokasikan sebesar Rp 60 triliun, dan untuk Tahun 2019 alokasi dana desa sebesar Rp 73 triliun.

Tabel 1. Persentase Penyerapan Anggaran Alokasi Dana Desa

\begin{tabular}{|c|c|c|c|}
\hline Tahun & Alokasi (Triliun) & Anggaran (Triliun) & (\%) Penyerapan \\
\hline 2015 & 20,8 & 17,2 & $82,7 \%$ \\
\hline 2016 & 47 & 45,9 & $97,7 \%$ \\
\hline 2017 & 60 & 59,1 & $98,5 \%$ \\
\hline 2018 & 60 & 59,4 & $99,0 \%$ \\
\hline
\end{tabular}

Sumber: Diolah dari berbagai sumber, 2019 
Gambar 3. Penyerapan Alokasi Dana Dasa

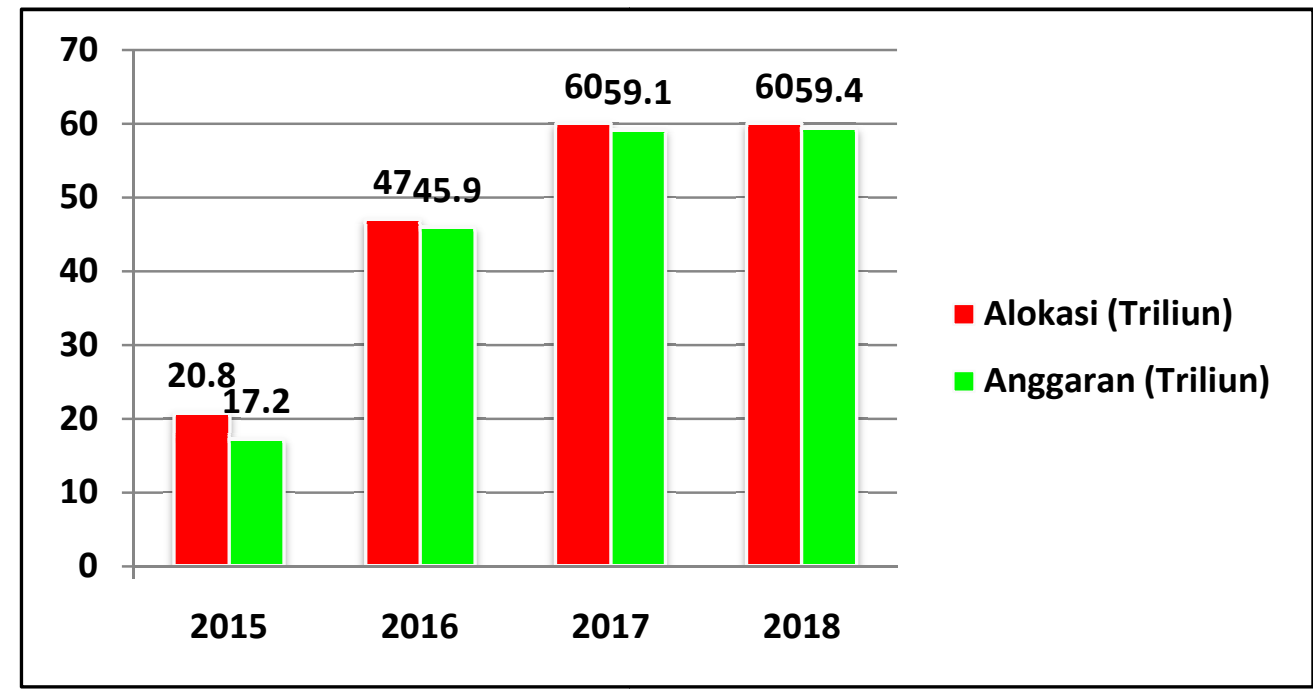

Sumber: Diolah dari berbagai sumber, 2019

Dilihat dari kinerja penyerapan programdana desa yang dipantau, memang secara ouput kegiatan penyerapan dana desa dapat tergolong berhasil secara kegiatan. Akan tetapi, persoalan-persoalan yang terjadi dilapangan ditemukan tidaklah demikian adanya sebagaimana fakta yang terjadi di desa-desa sekitaran Kawasan Eksplorasi Tambang Migas di Bojonegoro.Fakta dilapangan banyak ditemukan penyalahgunaan Dana Desa, jika ditelusuri secara kemanfaatan program/kegiatan.Masih banyak kegiatan yang berasal dari Dana Desa tidak melihat keterjangkauan kemanfaatan atau bahkan para pelaku program/kegiatan sendiri (pengelola dana desa) tidak paham akan penggunaan kegiatannya. Sehingga, persoalan ini menjadi pekerjaan rumah yang luar biasa bagi pemerintah daerah dalam hal pengendalian Dana Desa yang ada.

Beberapa penyalahgunaan Dana Desa yang dihimpun oleh penulis dari data laporan ICWsetiap tahunnya dapat diidentifikasi disebabkan karena longgarnya pengawasan dan kewenangan terhadapKepala Desadalam mengelola Dana Desa. Kewenangan Kepala Desa yang terlalu besar diduga karena (Badan PermusyawaratanDesa) BPD yang seharusnya berfungsi sebagai pengawas tidak menjalankan tugasnya dengan baik. Selain itu kebanyakan anggota BPD dari tokoh masyarakat dan adat juga ikut terlibat "bermain" dalam mengelola dana desa ini, kasus yang hampir serupa juga diindikasikan oleh penulis terjadi di desa-desa yang menjadi bahan kajian penulis. Pada tahun 2017 setidaknya ditemukan 96 kasus 
penyalahgunaan pengelolaan dana desa. Kasus ini meningkat dari tahun 2016 sebanyak 41 kasus dan tahun 2015 sebanyak 15 kasus.

Gambar 4. Jumlah Kasus Penyalahgunaan Alokasi Dana Dasa

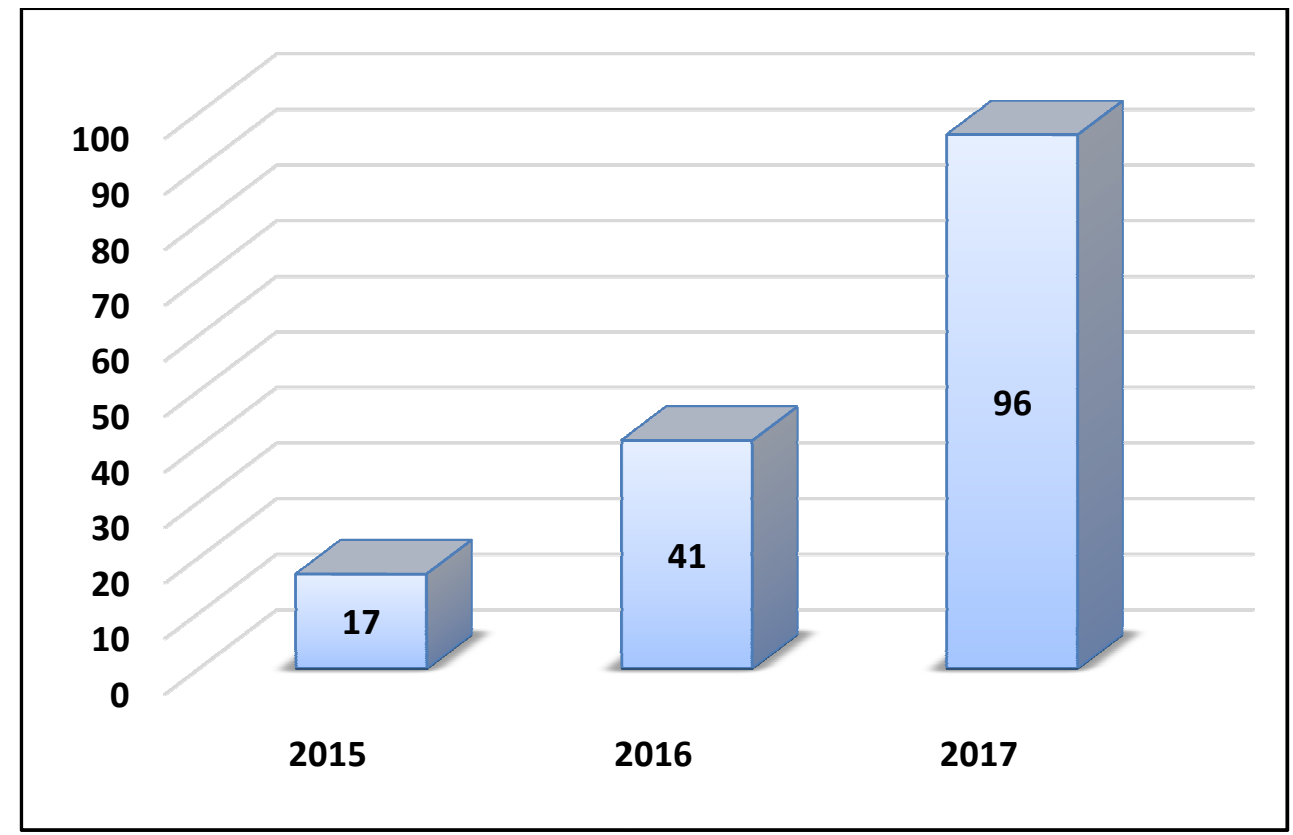

Sumber : Indonesia Coruption Watch (ICW), data diolah penulis 2019

Dari kebanyakan kasus yang terjadi, pada umumnya penyalahgunaan anggaran dilakukan pada: (1) proses penyusunan Alokasi Dana Desa, (2) Penggunaan (Implementasi Dana Desa), (3) pemanfaatan Kas Desa, dan (4) Pungutan yang dilakukan oleh Aparat Desa. Modus yang terjadi danmudah dilakukan oleh oknum aparat desa, diantaranya adalah (1) praktik penyalahgunaan anggaran sebanyak 51 kasus, (2) pembuatan laporan fiktif sebanyak 17 kasus, (3) kegiatan/proyek fiktif sebanyak 15 kasus dan (4) penggelembungan anggaran sebanyak 14 kasus. Dari kejahatan penyalahgunaan Dana Desa tersebut, kerugian negara yang ditimbulkan pada tahun 2015 sebanyak Rp 9,12 miliar. Kemudian menurun di tahun 2016 sebanyak 8,33 miliar dan pada tahun 2017 terjadi peningkatan yang signifikanatas kerugian negara mencapai 30,11 miliar. Melihat fakta di atas terasa masih sangat jauh dari kondisi ideal mengenai sebuah konsep kebijakan pembangunan desa, seperti yang diutarakan oleh Maskun Sumitro, yang menyebutkan bahwa Kebijaksanaan Pembangunan Wilayah Pedesaan dirumuskan secara umum dan merata dan menjadi pedoman setiap langkah Pembangunan Sektoral di Bidang Pedesaan, yang meliputi semua 
sektor unggulan yang dimiliki oleh desa tersebut. ${ }^{8}$ Padahal menurut Menurut Garna, pembangunan yang tepat untuk desa adalah yang akomodatif terhadap modernisasi tetapi tidak meninggalkan tradisi sebagai akar kehidupan yang merupakan identitas atau karakteristik masyarakat. ${ }^{9}$

Gambar 5. Kerugian Negara Akibat Penyalahgunaan Alokasi Dana Dasa

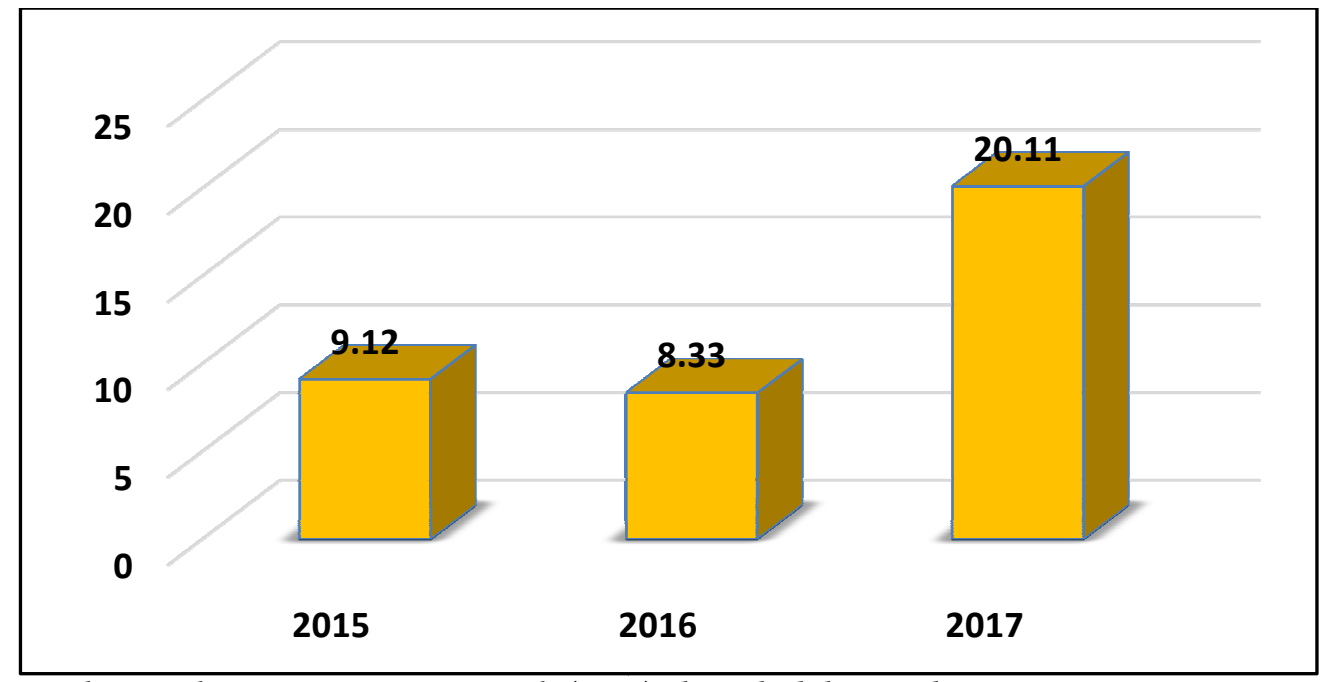

Sumber : Indonesia Coruption Watch (ICW), data diolah penulis 2019

Dari sekian banyaknya kasus, modus dan kerugian yang disebabkan oleh para actor penyalahgunaan dana desa yang terjerat dimana sebagian besar adalah Kepala Desa. Sebanyak 65 Kepala Desa tersangkut kasus pada tahun 2017, 32 Kepala Desa tersangkut pada tahun 2016 dan 15 Kepala Desa terjerat kasus pada di tahun 2015. Sehingga total 112 Kepala Desa sudah terjerat kasus penyalahgunaan dana desa semenjak 2015.

Melihat kasus-kasus tersebut di atas menarik kemudian untuk mencoba kita lihat konsep pencegahan yang ditawarkan oleh Utomo yang menitik beratkan pada pelibatan peran serta semua elemen desa,menurutnya penerapan otonomi daerah dan desa memerlukan dukungan dan pengembangan suatu sistem pengelolaan

${ }^{8}$ MaskunSumitro, Pembangunan Masyarakat Desa, (Yogyakarta: Media Widya Mandala, 1994) 49.

${ }^{9}$ GarnaKartasamita, Pembangunan untuk rakyat, memadukan pertumbuhan dan pemerataan, (Jakarta : CIDES, 1996), 89. 
pembangunan yang lebih mendorong keterlibatan masyarakat secara lebih luas. ${ }^{10}$ Dalam pemerintahaan perlu ditumbuhkan perilaku pemerintahan yang jujur, terbuka, bertanggung jawab, dan juga demokratis (good governance).

\section{E. Re - Orientasi Pemanfaatan Dana Desa Dalam Rangka Peningkatan Sumber Daya Manusia untuk Pertumbuhan Berkualitas.}

Melihat kondisi demikian, sebagaimana penulis sampaikan. Tentu saja bukan hal yang menggembirakan meskipun diluar kasus itu banyak juga beberapa desa yang berhasil memanfaatkan dana desa dengan baik dan efisien serta inovatif.Dengan banyaknya gambaran pembangunan desa sebagaimana diuraikan diatas, terlihat bahwa dana desa masih belum cukup memberikan hasilyang signifikan terhadap perkembangan pembangunan dan ekonomi di desa. Dengan belum maksimalnya pembangunan di desa hingga saat ini, maka penulis ingin memberikan kontribusi pemikiran khususnya bagaimana menata dan merumuskan kembali model penataan dana desa khususnya focus untuk peningkatan sumberdaya manusia untuk membangun pertumbuhan ekonomi yang berkualitas. Sebelumnya, penulis juga telah melakukan analisis dan pemetaan terhadap implementasi dari peraturan kebijakan tentang desa beserta turunanya, pertama: apakah telah dilaksanakan hingga menyeluruh dari kebijakan dan amanat undang-undang beserta turunanya yang mengatur mengenai desa serta kedua:apakah aparatur negara dan aparatur desa yang terlibat dalam pelaksanakan peraturan desa tersebut telah melaksanakan kebijakan tersebut dengan benar dan menyeluruh.

Adapun beberapa pemikiran penulis yang sekiranya merupakan bagian atau tahapan dalam model penataan dana desa yang dapat dilakukan oleh Pemerintah Daerah khususnya Kabupaten Bojonegoro adalah Membangun Desa Maju Berintegritas melalui Dana Desa. Berikut ini adalah alur konsep bagaimana "Membangun Desa Maju Berintegritas melalui Dana Desa":

${ }^{10}$ Slamet JokoUtomo,Implementasi Kebijakan Anggaran Pendapatan dan Belanja Desa (ABDesa)untuk Meningkatkan Pembangunan Desa. Media Trend, Vol. 10 No. 1 Maret 2015. 
Gambar 6. Konsep Pembangunan Desa Maju Berintegritas melalui Cara

Pemerintah Melalukan Intervensi terhadap Rakyatnya

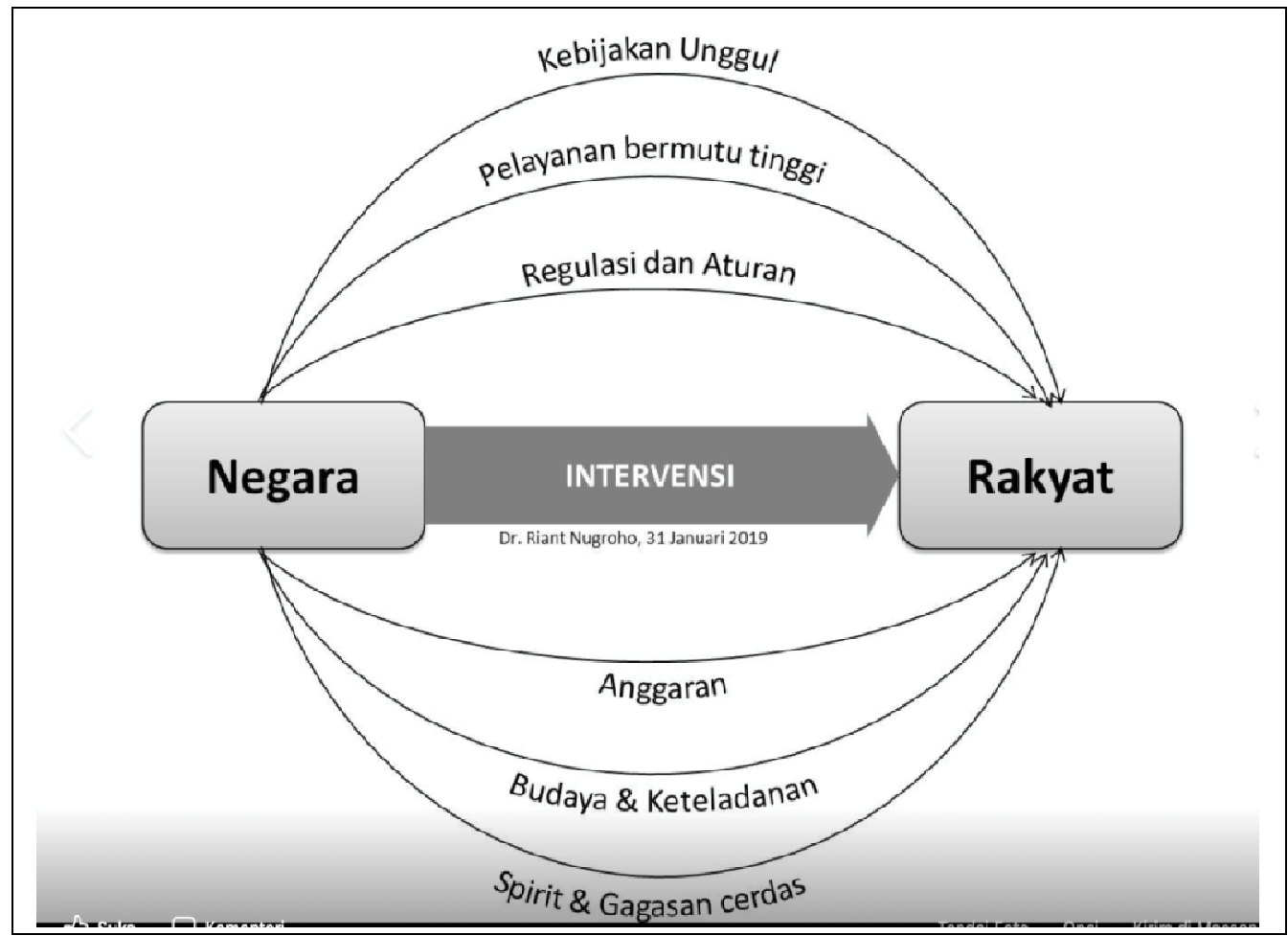

Sumber: Institute for Policy Reform, 31 Januari 2019

Negara yang dalam hal ini adalah Pemerintah Daerah. Pemerintah Daerahmusti tanggap dan wajib hadir memberikan intervensi untuk kepentingan rakyat dengan melalukan Evaluasi Ex-Ante Dalam Rangka Penyiapan Inisiasi Program/Kegiatan Strategis Pengelolaan Dana Desa serta menyiapkan para pemangku kebijakan tersebut untuk secara teknis dapat menguasaidimensi utama: (1) spirit \& gagasan cerdas, (2) budaya \& keteladanan, (3) Anggaran, (4) Regulasi dan Aturan, (5) Pelayanan bermutu tinggi, dan (6) menghasilkan output kebijakan unggul $\rightarrow$ penyusunanprogram/kegiatan ungguldi desa sehingga dapat mengubah setiap sumberdaya menjadi asset dan kekayaan desa.Adapun setelah dilakukan evaluasi, output teknis yang sekiranya selaras dengan "Tema RKP 2020 Peningkatan Sumber Daya Manusia untuk Pertumbuhan Berkualitas" adalah melakukan fasilitasi penyiapan Inisiasi Program/Kegiatan Strategis Pengelolaan Dana Desa melalui penyelenggaraan Pelatihan untuk Pelatih (TOT) $\rightarrow$ ditujukan secara khusus kepada Fasilitator Desa, untuk kemudian dapat melatihkan dimensi 
utama penyusunan program/kegiatan unggul di desa serta menularkan mental anti korupsi kepada para pelaku/pengelola dana desa di Bojonegoro.

Tawaran ini sejalan dengan apa yang disampaikan oleh Nurliana,yang menyebutkan bahwa terdapat konsekuensi nyata dari pemberian kewenangan otonomi terhadap desa maka perlu diatur pula secara tegas sumber-sumber pembiayaan yang harus diperoleh Desa khususnya yang berasal dari pemerintahan ditingkat atasnya. ${ }^{11}$ Aturan dan undang-undang tersebut akan mampu diterjemahkan dan dipahami dengan baik oleh penyelenggara desa dengan dilakukannya peningkatan sumber daya yang dimiliki salah satunya dengan cara mengikutkan mereka pada program pelatihan atau workshop.

Pendidikan Penyusunan Program/Kegiatan Unggulyang dikemas dalam bentuk Pelatihan untuk Pelatih (TOT)bagi para Fasilitator Desa secara teknis dilaksanakan dalam bentuk: (1) Program Bimbingan Teknis dalam pembuatan RPJMDes dalam pengajuan dan pencairan dana desa, dalam hal ini melibatkan kepala desa dan aparatur desa secara langsung atau masyarakat desa setempat yang ditunjuk dan dianggap akan mampu nantinya melaksanakan dan membuat RPJMDes untuk desa tersebut, (2) Program Bimbingan Teknis dalam Pembuatan Laporan Pertanggung Jawaban kegiatan desa dan Rincian Anggaran Biaya (RAB) kegiatan yang di dalamnya meliputi pertanggung jawaban invoice pembelian suatu barang/jasa/material pada pemanfaatan dan penggunaan Dana Desa, dalam hal ini melibatkan kepala desa dan aparatur desa secara langsung atau masyarakat desa setempat yang ditunjuk dan dianggap akan mampu nantinya melaksanakan dan membuat RPJMDes untuk desa tersebut, (3) Program pembinaan dalam dalam meningkatkan kompetensi aparat desa sebagai pengelola kebijakan dan pengelola keuangan desa dalam pemanfaatan dana desa pada sektor pembangunan desa dan sektor pemberdayaan masyarakat desa dengan memajukan sumber perekonomian desa, (4) Program pelatihan bagi masyarakat desa dalam memanfaatakan sumberdaya alam atau sumberdaya manusia yang terlatih yang disesuaikan dengan keahlian dan sumberdaya alam setempat dalam pemanfaatan sektor pariwisata setempat dan sektor ekonomi kreatif lokal setempat, (5) Program peningkatan keahlian dan peningkatan nilai produk lokal setempat yang ada di desa tersebut untuk lebih bisa ditingkatkan kembali pada kualitas produk dengan mendatangkan ahli yang memiliki kompetensi di bidang nya, misalkan pada desa

${ }^{11}$ Nurliana, Pengelolaan Alokasi Dana Desa (ADD) Dalam Pembangunan Fisik di Desa Sukomulyo Kecamatan Sepaku Kabupaten Penajam Paser Utara. Ejournal Administrasi Negara, Vol. 1 No 3, 35. 
yang memiliki bidang fashion produk batik atau tenun bisa kita datangkan ahli atau desainer fashion untuk mengkolaborasi produk batik tersebut dengan ide atau gagasan desainer tersebut bagusnya batik/tenun tersebut dibuat untuk lebih memiliki nilai tambah dan nilai jual di pasaran. Jika pada desa penghasil kuliner, maka dapat memafaatkan kuliner asli dari daerah tersebut untuk ditingkatkan kembali kualitas makanan tersebut misalkan dengan mendatangkan chef/ahli makanan atau ahli branding dan packaging dalam pengemasan produk makanan yang dihasilkan agar memiliki nilai jual yang lebih di pasar, (6) Program membuat koperasi mandiri desa dalam membantu pemanfaatan dana desa dalam memberikan modal untuk masyarakat desa yang membutuhkan modal, dan (7) Membuka akses pasar pada produk-produk desa agar bisa diminati oleh investor atau retail untuk memasarkan produk yang di hasilkan oleh desa tersebut.

Langkah berikutnya setelah melakukan fasilitasi penyiapan Inisiasi Program/Kegiatan Strategis Pengelolaan Dana Desa melalui penyelenggaraan Pelatihan untuk Pelatih (TOT) $\rightarrow$ ditujukan secara khusus kepada Fasilitator Desa yaitu menetapkan jejaring Komunitas Fasilitator Desa dalam struktur jenjang komunitas berbasis Teknologi Informasi Desa di bawah Kepala Derah dan sekaligus pengenalan potensi unggul tiap masing-masing daerahsebagai gerakan desa maju. Dalam ruang lingkup ini, meliputi:

(1) Membentuk fasilitator unggulan (dalam struktur jaringan komunitas).

(2) Penyusunan konsep transfer knowledge dalam membangun gerakan desa maju.

\section{F. PENUTUP}

\section{Kesimpulan}

Alokasi dana desa (ADD) yang bersumber dari dana perimbangan keuangan pemerintah pusat dan daerah keberadaanya sangat mempengaruhi laju pertumbuhan setiap desa. Demikian halnya dengan beberapa desa di Bojonegoro dengan adanya ADD saat ini maka desa tersebut sangat terbantu dalam melaksanakan pembangunan desa secara bertahap demi terwujudnya kesejahteraan masyarakat.Pada sisi lainnya terkait keberadaan ADD maka pemerintahan desa tersebut perlu meningkatkan pengetahuan SDM pemerintahan desa dalam mengelola dan menggunakan keuangan ADD sebagaimana yang diharapkan dari peraturan perundang-undangan yang berlaku.Jika beberapa hal dalam pembahasan diatas dapat diterapkan, peluang 
desa tersebut menjadi semakin maju sangat terbuka lebar, apalagi di era persaingan yang sangat ketat seperti saat ini.

\section{Rekomendasi}

Dari kesimpulan diatas dapat disarankan hal-hal sebagai berikut :

a. Kiranya pemerintah pusat dan pemerintah daerah dapat memberikan pengetahuan dibidang pengelolaan keuangan bagi aparatur pemerintahan Desa.

b) Keberadaan ADD pada tiap tahunnya diharapkan dapat terjadi peningkatan. 


\section{Daftar Pustaka}

Bempah, Ridwan. 2013. Analisis Alokasi Dana Desa dalam Meningkatkan Pendapatan Penduduk Miskin di Kecamatan Poso Pesisir Kabupaten Poso. E-Jurnal Katalogis, Vol. 1 No. 2, April 2013

Kartasamita, Garna, 1996. Pembangunan untuk rakyat, memadukan pertumbuhan dan pemerataan.Jakarta : CIDES

Nurliana. 2013. Pengelolaan Alokasi Dana Desa (ADD) Dalam Pembangunan Fisik di Desa Sukomulyo Kecamatan Sepaku Kabupaten Penajam Paser Utara. Ejournal Administrasi Negara, Vol. 1 No 3

Maskun, Sumitro, 1994, Pembangunan Masyarakat Desa, Media Widya Mandala :Yogyakarta

Ndraha, Taliziduhu. 1997. Metodologi Ilmu Pemerintahan, Jakarta : Rineka Cipta.

Surjadi, 1995, Pembangunan Masyarakat Desa, Bandung: Mandar Maju.

Utomo, Slamet Joko. 2015. Implementasi Kebijakan Anggaran Pendapatan dan Belanja Desa (ABDesa) untuk Meningkatkan Pembangunan Desa. Media Trend, Vol. 10 No. 1 Maret 2015

Wasistiono, Sadu. 2006. Prospek Pengembangan Desa. Bandung: Fokusmedia.

Widjaja, HAW. 2003. Otonomi Desa. Jakarta : PT Raja Grafindo Persada.

Sumber: http://www.bojonegorokab.go.id,Indonesia Coruption Watch (ICW), dan Institute for Policy Refor. 
